\title{
USG Evaluation of Cholelthiasis in Relation to 5Fs Mnemonics in Addition to Two Other Factors Like Family History and Food
}

\author{
Authors \\ Dr. Rudra Narayan Dash ${ }^{1}$, Dr. Gitanjali Satpathy ${ }^{2}$ \\ ${ }^{1,2}$ Asst. Professor (Radio-Diagnosis) Kalinga Institute of Medical Sciences (KIMS) KIIT University, \\ Bhubaneswar \\ Corresponding Author \\ Dr. Gitanjali Satpathy
}

Asst. Professor (Radio-Diagnosis) Kalinga Institute of Medical Sciences (KIMS) KIIT University,

Bhubaneswar, Odisha.

\begin{abstract}
Cholelthiasis is a gall bladder disease which is called Gall Bladder Stone Disease (Stone/Calculus in Gall Bladder). Now-a-days, it is not restricted to Western Countries but it is increasing in Asian Countries too. Cholelthiasis (Gall Bladder Stone) disease is now a common ailment in India as well as in Odisha.

There are many risk factors which influence Gall Stone formation, Out of which 5Fs mnemonics are common to remind the public. These 5Fs are Female, Forty, Fertile, Fatty and Fair. However besides 5Fs we have taken another two factors in our study which also play a role in formation of stone in gall bladder which are family history and food habit.

In our study it is observed that females in reproductive group of the age above 40 years and obese, having bad food habits are more prone to suffer from Cholelthiasis (Gall Bladder Stone) Disease than others. Therefore the main focus of our study is not only to do research of the disease but also to educate public through our study about the disease and also to prevent from Cholelthiasis disease. The results were analysed and tabulated taking different parameters into consideration. We have given emphasis on female gender excluding males in our study.

Key Words: Cholelthiasis (Gall Bladder Stone) Disease, 5Fs mnemonics, Family history, Food habit.
\end{abstract}

\section{Introduction:-}

Cholelthiasis (Gall Bladder Stone) Disease is now a common and significant health problem in developing as well as in developed countries. Gall Bladder Stone Disease (Cholelthiasis) remains one of the major causes of abdominal morbidity and mortality throughout the world. Cholelthiasis is a chronic recurrent hepatobiliary disease. It is characterised by the formation of stone in the Gall Bladder, Common bile duct (CBD), Hepatic Bile Duct. 
The basis of this disease is the impaired metabolism of cholesterol, bilirubin and bile acid. More than 20 million Americans suffer from Gall stone disease and 80,000 patients are hospitalised for Cholelthiasis every year. Prevalence rate of Cholelthiasis across Asian population is 5 to 20 percent and Black Americans 13.9 percent of women. Lowest frequency is seen in Black Africans which is less than 5 percent.

In developing country like India, this disease is rapidly rising since 2000 . Though there are different claims in different parts of India on prevalence rate of Cholelthiasis disease, it is clear as whole in India; there is increase in prevalence rate of patients suffering from Cholelthiasis. After the introduction of Laparoscopic cholecystectomy in 1989, this surgery is increasing in all parts of India because it is most acceptable and an elective abdominal surgery which is less invasive. Surprisingly in Asian Countries besides Cholelthiasis disease, Choledocholithiasis (stone in common Bile duct), gall bladder cancer disease are increasing in India irrespective of East, West, North and South. Many research workers have studied that Cholelthiasis disease appears to carry higher risk of Gall bladder cancer.

Symptoms of Cholelthiasis disease are pain in upper abdomen, nausea and vomiting, digestive problems, clay coloured stool, could be associated with jaundice and fever.

The increasing rate of prevalence of Cholelthiasis could be due to multiple factors like 5Fs mnemonics. These 5Fs are Female, Forty, Fertile, Fatty and Fair. There are other risk factors which have been noted by many researchers. Therefore we took this study to evaluate the other two different factors in relation to USG findings of Cholelthiasis as family history \& food habits.

The accuracy of the diagnosis of Cholelthiasis (Gall Stone) Disease has been significantly improved through advanced radio-diagnosis modulations like Ultrasonography, CT, MRI and scintigram. Out of these, Ultrasonography is safe and low cost investigation for Cholelthiasis which has played a great role in the diagnosis of the disease. Ultrasonography also plays a great role in high accuracy of diagnosing Cholelthiasis than others.

\section{Materials and Methods:-}

The participants of our study were patients with Cholelthiasis (Gall Stone) Disease who were referred by different clinicians to Kalinga Institute of Medical Sciences, Bhubaneswar and 2 other diagnostic centres in Bhubaneswar for Ultrasonography examinations. A total of 614 patients (both male and female) were registered for our studies those were diagnosed to have Cholelthiasis (Gall Stone) Disease by Ultrasonography. The patients were from children to adult, (1 year to more than 6 years) including both sexes.

Our period of study was from January 2014 to December 2016.

Out of 614 patients who were diagnosed having Cholelthiasis (Gall Stone) Disease, 110 were male and 504 were female.

In our study, we have selected the female group only. Female genders are mostly affected by 5Fs mnemonics factors for the development of Cholelthiasis (Gall Stone) Disease.

In our study we included the following factors:

5 Fs - (i) Female, (ii) Forty, (iii) Fertile, (iv) Fatty and (v) Fair

Other two factors - (i) Family History (ii) Food habits

We collected the different data's from history of the patients as well as from the records the patients have, which were tabulated and analysed further for our study.

We categorised the patients as per age, sex, parity (fertility), fair, fatty, family history and food habits.

BMI of the patients were recorded according to the definition as suggested by the WHO criteria for Asia-Pacific Region. The family history and food habits were taken from the patients about the suffering from Cholelthiasis in their family. High calorie diet is defined as the diet which gives to the body more than 4000 calories per day means 
the food is rich in contents of high protein, fat, carbohydrates and minerals. These diets include more dried fruits and nuts, chocolate, ghee and cheese, fish oil, butter, whole milk, oily food, fish and meat, more consumption of egg, fast and fried food, saucy and gravy foods, potato chips, caramel, mayonnaise etc. We took the history of the patients as per food habits.

\section{Results}

The results were recorded as per the 5Fs mnemonics, Family history and Food habits.

\section{(1) Females}

In our study from total of 614 cases of Cholelthiasis, 110 were males and 504 were females. Females were more than males.

\begin{tabular}{|c|c|c|c|}
\hline Sl.No. & Sex & Number & Percentage (\%) \\
\hline 1 & Male & 110 & 17.91 \\
\hline 2 & Female & 504 & 82.08 \\
\hline & Total & 614 & \\
\hline
\end{tabular}

\section{(2) Forty}

Our study shows the following age group of female patients where the highest no. Of patients were the age group of 40 years $\&$ above.

\begin{tabular}{|c|c|c|c|}
\hline $\begin{array}{c}\text { Sl. } \\
\text { No. }\end{array}$ & Age (years) & Number & $\begin{array}{c}\text { Percentage } \\
(\boldsymbol{\%})\end{array}$ \\
\hline 1 & 60 \& Above & 121 & 24.007 \\
\hline 2 & 40 to 59 & 265 & 52.579 \\
\hline 3 & 20 to 39 & 100 & 19.841 \\
\hline 4 & 10 to 19 & 15 & 2.976 \\
\hline 5 & 9 and less & 03 & 0.595 \\
\hline & Total & 504 & \\
\hline
\end{tabular}

(In this study the age group of patients $40 \&$ above are 386 , that is almost $86.58 \%$ )

\section{(3) Fortile}

Our study shows 345 (68.45\%) numbers of females who delivered more than one children are more in number out of 504 cases.

\section{(4) Fair}

Only 96 females (19.07\%) out of 504 cases were fair in our study.

\section{(5) Fatty}

Out of 504 cases, 87 (17.261\%) were overweight and $97((19.24 \%)$ were obese.

\section{(6) Family History}

Only 91 (18.055\%) were having family history of suffering from Cholelthiasis (Gall stone Disease)

\section{(7) High Calorie Diet}

Our study showed that, 249 females (49.404\%) were having history of consuming high calorie diet.

\section{Discussion}

Our study shows female group likely to have more risk of suffering Cholelthiasis as percentage of females is more to have gall stones. In females, the oestrogen plays an important role. Liver is stimulated by oestrogen to remove more cholesterol from the blood and divert into the bile. Females who have one or more child also are more prone to develop Cholelthiasis, which shows that increase risk of Cholelthiasis in females is therefore related to oestrogen effect, pregnancy, use of oral contraceptives and hormonal therapy. Many literatures show that in pregnancy, oestrogen level is increased which initiate the formation of biliary sludge which is composed of cholesterol, calcium biliuriate of 5 to $30 \%$ of pregnant women.

After delivery of the baby (during post partum period), biliary sludge disappears in $2 / 3^{\text {rd }}$ of the cases but in $1 / 3^{\text {rd }}$ cases gall stone disease is established. Fatty factor (overweight and obese) in female plays an important role in formation of Cholelthiasis because having overweight and obesity are increased risk of developing Cholelthiasis. Overweight and obesity in late teenagers carries the greatest risk. Females having severe obesity shows on age adjusted relative risk of 5 to 6 times to develop Cholelthiasis than females having normal weight.

Obesity is associated with increased activity of rate limiting step in hepatic enzyme, 3- hydroxyl3-methyl-glutaryl co-enzyme A (HMG-COA) reductase, leading to cholesterol synthesis in the liver and enhanced its secretions into the bile.

So enhanced level of cholesterol secretion from liver, bile super saturation and loss of gall bladder contractibility is the mechanism of formation of Cholelthiasis.

Family history factor (genetics) also plays a role in developing Cholelthiasis. A female having a 
history of a family member or close relative suffering from Cholelthiasis may have more increased rate than others.

Many studies show that genetics along with environmental and diet factors can accelerate the formation of gall stone, particularly diet -gene interaction. Several genes are associated with Gall Stone Disease. Out of these following are the important:

1. Apolipo protein -E (Apo- E)

2. Apolipo protein -B (Apo-B)

3. Cholesterol Ester transporting protein (CETP)

4. Cholesterol Kinin receptor A ( CCKA)

5. ATP binding cassette sub family $\mathrm{G}$ member -8 ( ABCG -8)

From many studies it has been noted that mutation or defect in genes with many other factors plays a complex role in formation of Cholelthiasis (Gall Stone) Disease. In our study $18.055 \%$ females have family history of gall stone disease.

Our study shows that $249(58.33 \%)$ females having Cholelthiasis consume high calorie diet. In other words, females consuming higher calorie diet are in a higher risk of developing Cholelthiasis (Gall Stone) Disease than others.

\section{Conclusion}

Our Study has defined 5F mnemonics, the risk factors along with the other two risk factors such as family history and food habit. In conclusion it is clear that female above the age of 40 years with parity, overweight and obesity can have Cholelthiasis (Gall Stone) Disease in future. Consumption of high calorie diet can be risk factor in female in formation of Cholelthiasis (Gall Stone) Disease. Females who are non obese or having no overweight and not consuming high calorie diet are at less risk. Fair factor plays a little role in our country.

We conclude that, factors 5Fs mnemonics along with family history and food habits play an important role in formation of Cholelthiasis (Gall Stone) Disease. It is also noted from our study that prevalence rate of Cholelthiasis (Gall Stone) Disease is increasing in children.
It is also advised if a pregnant woman complains of pain in abdomen should undergo USG evaluation to exclude Cholelthiasis, during antenatal period \& postpartum period.

Any female gender should have periodical check by USG to exclude Cholelthiasis (Gall Stone) Disease if there is family history.

\section{References}

1. Dr.Alok Chandra Prakash, Dr. Samir Toppo, Dr.Vinay Pratap - "Prevalence and management of Cholelthiasis in East India", IOSR Journal of Dental and Medical Sciences, Vol.15, Issue-12 (Dec.2016), Pg33-34

2. Sarin SK, Kapur BM, Tandon RK "Cholesterol and pigment stone in Northen India - A prospective analysis", Dig., Dis.Sci (1986 -Oct)-31(10), 1041-1045

3. Janson L Apselin P, Erikson S, Hildell J, Trell E, Ostberg H - "Ultrasonographic screening for Gallstone Disease in middle aged women -Detection rate, symptoms and biochemical features", Scand Journal Gastoentrol - (1985 Aug), 20(6),706-10.

4. K. Sai Sandeep, Gowri Shankar Singaraju, Prasad Mandava, Venkata N. Bhavikati and Rohit Reddy - “ Evaluation of body weight, body mass index and body fat percentage changes in early stage of fixed orthodontic therapy"- JISPCD (Journal of International Soc. Prev. Community Dist,), -2016, Jul-Aug. 6(4) - 349-358.

5. Laura M. Stinton \& Edlon A. Shaffer "Epidemiology of Gall Bladder Disease : Cholelthiasis and Cancer", Gut Liver 2012, April-6(2),172-174.

6. Shaffer EA : "Epidemiology and risk factors for Gall Stone Disease : Has the Paradigm changed in $21^{\text {st }}$ Century?". Curr. Gastroenterol Rep.2005, 7:132-140.

7. Tazima S.: "Gall stone disease epidemiology, pathogenesis and classification of biliary stones (Common Bile Duct and Intraheptive)”, Best 
Practices Res. Clin. Gastroesterol, 2006, 20:1705-1083.

8. Travers O Liu: "Clinical Manifestations and Impact of Gall Stone Disease", AM. J. Surg., 1993-165-45-409.

9. Shaffer EA: "Gall stone disease : Epidemiology of Gall Bladder stone Disease", Best Pract. Res. Clin. Gastroenterol 2006-20-981-986.

10. Singh V., Trikha B, Nain C, Singh K, Bose S: ": Epidemiology of Gall Stone Disease in Chandigarh : A community based study",

.Gartoenterol.Hepatol,2001:16:560-56.

11. Buch S., Schafinayer C., Voltake H et.al.," A genome wide association scan identifies the hepatic cholesterol transporter ABCG8 as a susceptibility factor for human Gall Stone Disease", at Genet.2007:39-995-997.

12. Grinhige F., Acalovschi M., Tirziu S. Et.al.:'Increased Gall stone risk in human conferred by common variant of hepatic ATP binding cassette transporter for cholesterol", Hepatology-2007:46:793801.

13. Einarsson K., Nilsell K., Leijd B., Anjenlin B.:'Influence of age on secretion of cholesterol and synthesis of bile acids by liver", N Eng. J. Med.1985:313:227282.

14. Volzke H., Baumeister SE, Alte D. Et.al: "Independent risk factors of Gall stone formation in a region with high Cholelthiasis prevalence." Digestion. 2005, 71:97-105.

15. Cirillo DJ., Wallace RB., Rodabough R J. Et.al. "Effect of Oestrogen therapy on Gall Stone Disease", JAMA， 2005:293:330339.

16. Thijis C, Kanipschild P.," Oral Contraceptives and the risk of Gall Bladder Disease : A meta analysis", AM. J. Public Health: 1993:83:1113-1120.
17. Maringhini A., Ciambra M., Baccelliere P. Et.al - "Biliary Sludge and Gall Stone in pregnancy: incidence, risk factors, and national history." , Ann. Int. Mede. 1993:119:116-120.

18. Valdivieso V., Covarrubias C., Siegel F., Cruz F.: " Pregnancy and Cholelthiasis: pathogenesis and natural course of galls stone diagnosed in early puerperium.", Hepatology: 1993:17:1-4.

19. Amral J F., Thompson W R.,"Gall Bladder disease in the morbidity obese", AM. J. Surg. 1985-149:551-557.

20. Ealinger S., "Gall stone in obesity and weight loss", Sur. J. Gastroenterol. Heptol. 2000.12.1347-1352.

21. Everhart JE, "Contribution of obesity and weight loss to Gall Stone Disease.", Ann. Int. Med. 1993:199:1029-1035.

22. Jargensen T., Jargensen L M.," Gall stone and Diet in Danish population", Scand J. Gastroenterol. 1989:24:821-826.

23. Mendez- Sanchez N., Zamova -Vades D. , Chavez - Tapia NC., Uribe M., "Role of diet in cholesterol gall stone formation.", Clin. Chim. Acta 2007:376:1-8.

24. Cuevas A., Miquel F, Reyes MS., Zanlung S., Nervi F., "Diet as a risk factor for cholesterol gall stone disease", J. AM. Coll. Nutr. 2004:23:187-196.

25. Tseng M., Everhart JE, Sandlers RS, "Dietary intake and gall bladder disease:A Review", Public Health Nutr. 1999:2:161172.

26. Lee Dw., Gilmore C J., Bonorris G. Et.al "Effect of dietary cholesterol on biliary lipids in patients with gall stone and normal subjects.", Am. J. CLin. Utr. 1985:42:414-420.

27. Seragg R K, Mc. Michael A, Baghurst PA, "Diet, alcohol and relative weight in gall stone disease : a case of control study.", Br. Med. J. (Clin.Res. Edn.), 1984:288:1113-1119. 
28. Kaechele V, Wabitsch M, Thiere D et. Al, "Prevalence of gallbladder stone disease in obese children and adolescents: influence of the degree of obesity, sex, and pubertal development.", J Pediatr Gastroenterol Nutr. 2006; 42(1):66-70.

29. Shaffer EA," Gallstone Disease: Epidemiology of gallbladder stone disease", Best Pract Res Clin Gastroenterol. 2006; 20(6):981-96.

30. Chung YJ, Park YD, Lee HC et. al.," Prevalence and risk factors of gallstones in a general health screened population." Korean J Med. DE 2007;72(5):480-490.

31. M J Stampfer K M Maclure G A Colditz Et.AL, "Risk of symptomatic gallstones in women with severe obesity ", The American Journal of Clinical Nutrition, Volume 55, Issue 3, 1992,652658.

32. SM Strasberg- "Acute calculous cholecystitis"- New England Journal of Medicine, 2008, 358(26)2804-2811- Mass Medical Soc.

33. NG Venneman, KJ van Erpecum, "Pathogenesis of gallstones"-

Gastroenterology Clinics, North. AM. 2010,39(2):171-83. 